\title{
PENGARUH PEMBERIAN EKSTRAK HABBATUSSAUDA TERHADAP KADAR GLUKOSA DARAH TIKUS PUTIH GALUR WISTAR JANTAN YANG DIINDUKSI ALOKSAN SEBAGAI UPAYA PREVENTIF HIPERGLIKEMIA
}

\author{
Yesi Nurmalasari ${ }^{1}$,Rakhmi Rafie ${ }^{2}$,Efrida Warganegara ${ }^{3}$,Indah Mulia Herwisdiane ${ }^{4}$ \\ Medical Nutrition Departement of Medical Faculty Malahayati University ${ }^{1}$ \\ Public Health Departement of Medical Faculty Malahayati University ${ }^{2}$ \\ Microbiology Departement of Medical Faculty Malahayati University ${ }^{3}$ \\ Medical Student of Medical Faculty Malahayati University ${ }^{4}$ \\ yesinurmalasari.dr@gmail.com
}

\begin{abstract}
Hyperglycemia is a medical condition in the form of an increase in blood glucose levels above normal levels which is a characteristic of several diseases, especially diabetes mellitus. One way to lower blood glucose levels is by using natural extracts of the Black Seed (Nigella sativa) plant. Black Seed (Nigella sativa) contains thymoquinone which can increase insulin sensitivity in body tissues and can also repair damaged $\beta$-cells of the pancreas, thereby increasing insulin secretion. Knowing the effect of Black Seed (Nigella sativa) extract on blood glucose levels of male Wistar rats (Rattus norvegicus) induced by alloxan as a preventive measure of hyperglycemia. True experimental research pre and post test with control group design. The sample used was 25 male rats divided into 5 groups. The variable studied was blood glucose levels. Data processing using SPSS. The mean $\pm S D$ GDP before treatment, after alloxan induction and after treatment at KM (126 $\pm S D 3.53),(128 \pm S D$ $3,24)$, and (124.6 $\pm S D$ 8,47), at $K N(121.6 \pm S D$ 7,17), (182.2 $\pm S D$ 18,11), and (149 $\pm S D$ 14,90), at $K P(122 \pm S D$ 3,53), (161.8 $\pm S D$ 6,76), and (108.4 $\pm S D$ 9,52), at P1 (123, $80 \pm S D 4,65),(139.8 \pm S D$ 1,48), and (100.8 $\pm S D$ 5,40), and at $P 2$ (122.6 $\pm S D$ 3,36), (164 $\pm S D$ 9,13), and (112.2 $\pm S D 4.71)$. Paired T-test showed a significant increase in blood glucose levels $(p<0.05)$ in the $K N(p=0.014), K P$ $(p=0.013)$, and $P 1(0.001)$ and $P 2(p=0.001)$ groups. except in the KM group $(p=0.683)$ because as a pure control One Way Anova test results blood glucose levels before and after treatment ( $p=$ 0.000) Post Hoc Bonferroni statistical analysis showed a significant difference in the KN group across all groups and an influential dose was the Black Seed Extract $150 \mathrm{mg} / \mathrm{kgBB}$ in the P1 group. There is an effect of giving Black Seed (Nigella sativa) extract as an effort to prevent hyperglycemia on blood glucose levels of male Wistar rats (Rattus norvegicus) induced by alloxan.
\end{abstract}

Keywords $\quad$ :Induction of Alloxan, Black Seed Extract (Nigella sativa), Blood Glucose Levels

\begin{abstract}
ABSTRAK
Hiperglikemia adalah suatu kondisi medis berupa peningkatan kadar glukosa darah melebihi kadar normal yang menjadi karakteristik beberapa penyakit terutama diabetes melitus. Salah satu cara untuk menurunkan kadar glukosa darah yaitu dengan ekstrak alami tanaman habbatussauda (Nigella sativa). Habbatussauda (Nigella sativa) mengandung thymoquinone yang dapat meningkatkan sensitivitas insulin di dalam jaringan tubuh dan juga dapat memperbaiki kerusakan sel- $\beta$ pankreas sehingga meningkatkan sekresi insulin. Mengetahui pengaruh pemberian ekstrak habbatussauda (Nigella sativa) terhadap kadar glukosa darah tikus putih (Rattus norvegicus) galur Wistar jantan yang diinduksi aloksan sebagai upaya preventif hiperglikemia. Penelitian eksperimental murni pre and post test with control group design. Sampel yang digunakan sebanyak 25 ekor tikus jantan dibagi menjadi 5 kelompok. Variable yang diteliti adalah kadar glukosa darah. Pengolahan data menggunakan SPSS. Nilai rerata \pm SD GDP sebelum perlakuan, setelah diinduksi aloksan dan setelah perlakuan pada KM (126 \pm SD 3,53), $(128 \pm$ SD 3,24), dan $(124,6 \pm$ SD 8,47), pada KN (121,6 \pm SD 7,12), $(182,2 \pm$ SD 18,11), dan $(149 \pm$ SD 14,90), pada KP (122 \pm SD 3,536), (161,8 \pm SD 6,76), dan (108,4 \pm SD 9,52), pada P1 $(123,80 \pm$ SD 4,65), (139,8 \pm SD 1,48), dan (100,8 \pm SD 5,40), dan pada P2 (122,6 \pm SD 3,36), (164 \pm SD 9,13), dan $(112,2 \pm$ SD 4,71). Uji Paired T-test menunjukkan peningkatan kadar glukosa darah yang bermakna
\end{abstract}


$(\mathrm{p}<0,05)$ pada kelompok KN ( $\mathrm{p}=0,014), \mathrm{KP}(\mathrm{p}=0,013)$, dan P1 (0,001) dan P2 ( $\mathrm{p}=0,001)$, kecuali pada kelompok KM ( $\mathrm{p}=0,683)$ karena sebagai kontrol murni. Hasil uji One Way Anova kadar glukosa darah sebelum dan setelah perlakuan $(\mathrm{p}=0,000)$. Analisis statistik Post-Hoc Bonferroni menunjukkan adanya perbedaan yang bermakna pada kelompok $\mathrm{KN}$ terhadap seluruh kelompok dan dosis yang berpengaruh adalah ekstrak habbatussauda $150 \mathrm{mg} / \mathrm{kgBB}$ pada kelompok P1. Terdapat pengaruh pemberian ekstrak habbatussauda (Nigella sativa) sebagai upaya preventif hiperglikemia terhadap kadar glukosa darah tikus putih (Rattus norvegicus) galur Wistar jantan yang diinduksi aloksan.

Kata Kunci : Induksi Aloksan, Ekstrak Habbatussauda (Nigella sativa), Kadar Glukosa Darah

\section{PENDAHULUAN}

Hiperglikemia adalah suatu kondisi medis berupa peningkatan kadar glukosa darah melebihi kadar normal yang menjadi karakteristik beberapa penyakit terutama diabetes melitus di samping berbagai kondisi lainnya (PERKENI, 2019). Menurut International Diabetes Federal (IDF) pada tahun 2015 menyatakan bahwa penderita hiperglikemia yang menuju diabetes mencapai 415 juta jiwa, dan diperkirakan akan mencapai 642 juta jiwa penderita hiperglikemia pada tahun 2040 (IDF, 2015). Berdasarkan Riskesdas, (2013) prevalensi hiperglikemia di Indonesia sebesar 2,1\%. Hiperglikemia ini akan berlanjut menjadi diabetes melitus yang tentunya sangat banyak kasusnya di seluruh dunia, dan apabila diabetes melitus tersebut tidak dilakukan penanganan dan pencegahan yang baik maka akan berpotensi menimbulkan komplikasi (Riskesdas, 2013).

Salah satu cara untuk menurunkan kadar glukosa darah yang meningkat selain dari memperbaiki pola hidup adalah dengan penggunaan obat antihiperglikemik atau obat antidiabetik. Namun, penggunaan obat antidiabetes biasanya berlangsung sangat lama bahkan bisa sampai seumur hidup, dengan efek samping yang ditimbulkan cukup besar. Maka diperlukan suatu jalan alternatif atau obat alternatif yang harganya dan khasiatnya tidak berbeda jauh dengan obat sintetik, salah satunya adalah pengobatan yang didapat dari ekstrak alami tanaman (Husna, 2008).

Habbatussauda (Nigella sativa) atau di Indonesia lebih dikenal dengan nama jintan hitam merupakan tumbuhan obat dari family Ranunculaceae. Habbatussauda memiliki banyak efek farmakologi yaitu anti diabetes, analgesik, anti inflamasi, anti mikroba, dan anti kanker. Ekstrak habbatussauda dapat menurunkan kadar glukosa darah normal pada tikus diabetes (Kaleem, dkk., 2006).

Kandungan volatil oil dalam habatussauda memiliki komponen utam thymoquinone (Husna, 2008). Thymoquinone dan senyawa lainnya yang terkandung dalam habbatussauda dapat meningkatkan sensitivitas insulin di dalam jaringan tubuh dan juga dapat memperbaiki kerusakan sel- $\beta$ pankreas sehingga meningkatkan sekresi insulin (Kanter, 2003; Benhaddou et al, 2008). Dalam penelitian yang dilakukan oleh Kriswandini, (2012) menggunakan ekstrak habbatussauda sebanyak $150 \mathrm{mg} / \mathrm{kgBB}$ kepada tikus putih model diabetes efektif dapat menurunkan kadar glukosa darah dan juga dapat memperbaiki tingkat kerusakan pulau Langerhans (Kriswandini, 2012).

Tujuan dari penelitian ini adalah untuk Mengetahui pengaruh pemberian ekstrak habbatussauda (Nigella sativa) terhadap kadar glukosa darah tikus putih (Rattus norvegicus) galur Wistar jantan yang diinduksi aloksan sebagai upaya preventif hiperglikemia.

\section{METODE}

Penelitian ini merupakan penelitian eksperimental murni (true-experiment) dengan desain penelitian pre and post test with control group design. Penelitian ini dilakukan pada bulan Januari 2021 Februari 2021 di Universitas Malahayati. Populasi dalam penelitian ini adalah tikus putih (Rattus norvegicus) galur Wistar jantan yang berusia 2-3 bulan dengan berat 
badan 150-200 gram berjumlah 30 sampel yang terbagi dalam 5 kelompok sampel, yaitu kelompok kontrol murni, kontrol negative, kontrol positif, kelompok perlakuan 1 dan kelompok perlakuan 2 yang jumlahnya didapatkan dengan rumus federer. Teknik pengambilan sampel yang digunakan adalah simple random sampling.

Kriteria inklusi bagi sampel adalah Tikus putih ( Rattus norvegicus) galur Wistar jantan, Sehat ( bergerak aktif dan rambut tidak mudah rontok), Berusia 2-3 bulan dan Berat badan 150 - 200 gram. Sementara untuk kriteria eksklusinya adalah terdapat kelainan anatomis, tikus sakit dan mati saat proses penelitian.

Instrumen penelitian ini menggunakan bahan-bahan seperti , ekstrak habbatussauda (Nigella sativa) dengan dosis $150 \mathrm{mg} / \mathrm{kgBB}$ dan $300 \mathrm{mg} / \mathrm{kgBB}$, aloksan dengan dosis $125 \mathrm{~mL} / \mathrm{kgBB}, \mathrm{NaCl}$, metformin, dietileter (ether), serbuk kayu, aquades, pakan hewan coba standar Comfeed BR-II,Comfeed BR-

2. Ekstrak habbatussauda diberikan selama 21 hari dam kadar glukosa darah diukur menggunakan glucometer.

Analisis univariat digunakan untuk mendeskripsikan distribusi frekuensi setiap variabel. Sementara analisis bivariat yang digunakan untuk penelitian ini adalah uji One-way anova test dan T-Test Paired Test dengan syarat telah dilakukan uji normalitas dan uji homogenitas. Tingkat kemaknaan (p) yang digunakan adalah $\mathrm{p} \geq 0,05$. Sementara untuk menganalisis perbedaan rerata antar kelompok lebih lanjut, digunakan tes Post-Hoc.

\section{HASIL}

Hasil pengukuran kadar glukosa darah tikus menunjukan adanya perbedaan kadar glukosa darah rerata pada tiap kelompok sebelum perlakuan, setelah diinduksi aloksan, dan setelah perlakuan.

Tabel 1 Rerata Kadar Glukosa Darah Tikus Sebelum Diberi Perlakuan

\begin{tabular}{llllll}
\hline & N & Mean & $\begin{array}{l}\text { Std. } \\
\text { Deviasi }\end{array}$ & Min. & Max. \\
\hline KM & 5 & 126,00 & 3,53 & 120 & 129 \\
\hline KN & 5 & 121,60 & 7,12 & 110 & 128 \\
\hline
\end{tabular}

\begin{tabular}{llllll}
\hline KP & 5 & 122,00 & 3,53 & 119 & 128 \\
\hline P1 & 5 & 123,80 & 4,65 & 118 & 129 \\
\hline P2 & 5 & 122,60 & 3,36 & 119 & 127 \\
\hline Total & 25 & 123,20 & 4,55 & 110 & 129 \\
\hline
\end{tabular}

Diketahui dari tabel 2 rerata kadar glukosa darah tikus pada kelompok KM yaitu 126 dengan nilai minimum dan maksimum 120 dan 129 , rerata pada kelompok KN yaitu 121,60 dengan nilai minimum dan maksimum 110 dan 128, rerata pada kelompok KP yaitu 122 dengan nilai minimum dan maksimum 119 dan 128 , rerata pada kelompok P1 yaitu 123,80 dengan nilai minimum dan maksimum 118 dan 129 , dan rerata pada kelompok P2 yaitu 122,60 dengan nilai minimum dan maksimum 119 dan 129.

Tabel 2 Rerata Kadar Glukosa Darah Tikus Setelah Diinduksi Aloksan

\begin{tabular}{llllll}
\hline Kel. & N & Mean & $\begin{array}{l}\text { Std. } \\
\text { Deviasi }\end{array}$ & Min & Max \\
\hline KM & 5 & 128,00 & 3,24 & 124 & 131 \\
\hline KN & 5 & 182,20 & 18,11 & 152 & 200 \\
\hline KP & 5 & 161,80 & 6,76 & 153 & 170 \\
\hline P1 & 5 & 139,80 & 1,48 & 138 & 142 \\
\hline P2 & 5 & 164,00 & 9,13 & 156 & 178 \\
\hline Total & 25 & 155,16 & 21,42 & 124 & 200 \\
\hline
\end{tabular}

Nilai rerata total pada seluruh kelompok adalah 155,16 dengan nilai minimum 124 dan nilai maksimum 200. rerata tertinggi terdapat pada kelompok $\mathrm{KN}$ dengan nilai 182,20 dan rerata terendah terdapat pada kelompok KM dengan nilai 128,00.

Tabel 3 Rerata Kadar Glukosa Darah Tikus Setelah Diberi Perlakuan

\begin{tabular}{llllll}
\hline Kel. & N & Mean & $\begin{array}{l}\text { Std. } \\
\text { Deviasi }\end{array}$ & Min & Max \\
\hline KM & 5 & 124,60 & 8,47 & 116 & 136 \\
\hline KN & 5 & 149,00 & 14,90 & 130 & 167 \\
\hline KP & 5 & 108,40 & 9,52 & 96 & 122 \\
\hline P1 & 5 & 100,80 & 5,40 & 96 & 110 \\
\hline P2 & 5 & 112,20 & 4,71 & 108 & 120 \\
\hline Total & 25 & 119,00 & 19,20 & 96 & 167 \\
\hline
\end{tabular}

Nilai rerata total pada seluruh kelompok adalah 119,00 dengan nilai minimum 96 dan nilai maksimum 167 . rerata tertinggi terdapat pada kelompok $\mathrm{KN}$ dengan nilai 149,00 dan rerata terendah terdapat pada kelompok P1 dengan nilai 100,80. 
Analisis selanjutnya menggunakan uji Paired T-Test, hasil penelitian yang dilakukan dan dianalisis menggunakan uji paired t-test terdapat perbedaan yang bermakna kadar glukosa darah sebelum dan setelah perlakuan $(\mathrm{p}<0,05)$ pada kelompok $\mathrm{KN}$ dengan nilai $\mathrm{p}=0,014$, kelompok KP dengan nilai $\mathrm{p}=0,013$, kelompok $\mathrm{P} 1$ dengan nilai $\mathrm{p}=0,001$, dan kelompok $\mathrm{P} 2$ dengan nilai $\mathrm{p}=0,001$. Kecuali kelompok KM tidak terjadi peningkatan glukosa darah karena tidak diinduksi aloksan dan tidak diberikan ekstrak habbatussauda. Hasil uji one way anova didapatkan perbedaan yang bermakna antar kelompok $(\mathrm{p}<0,05)$, yang berarti terdapat setidaknya 2 kelompok yang mempunyai perbedaan yang bermakna.

Tabel 4 Post Hoc Test

\begin{tabular}{|c|c|c|c|c|}
\hline \multicolumn{2}{|c|}{ KELOMPOK } & \multirow{2}{*}{$\begin{array}{l}\text { Mean } \\
\text { Difference } \\
\text { (I-J) }\end{array}$} & \multirow{2}{*}{$\begin{array}{l}\text { Std. } \\
\text { Error }\end{array}$} & \multirow{2}{*}{$\begin{array}{l}\text { Sig. } \\
0,005\end{array}$} \\
\hline KM & $\mathrm{KN}$ & & & \\
\hline & $\mathrm{KP}$ & 16,200 & 5,906 & 0,125 \\
\hline & $\mathrm{P} 1$ & $23.800^{*}$ & 5,906 & 0,007 \\
\hline & $\mathrm{P} 2$ & 12,400 & 5,906 & 0,487 \\
\hline \multirow[t]{4}{*}{$\mathrm{KN}$} & KM & $24.400^{*}$ & 5,906 & 0,005 \\
\hline & $\mathrm{KP}$ & $40.600^{*}$ & 5,906 & 0,000 \\
\hline & $\mathrm{P} 1$ & $48.200^{*}$ & 5,906 & 0,000 \\
\hline & $\mathrm{P} 2$ & $36.800^{*}$ & 5,906 & 0,000 \\
\hline \multirow[t]{4}{*}{$\mathrm{KP}$} & KM & $-16,200$ & 5,906 & 0,125 \\
\hline & $\mathrm{KN}$ & $-40.600^{*}$ & 5,906 & 0,000 \\
\hline & $\mathrm{P} 1$ & 7,600 & 5,906 & 1,000 \\
\hline & $\mathrm{P} 2$ & $-3,800$ & 5,906 & 1,000 \\
\hline \multirow[t]{4}{*}{ P1 } & KM & $-23.800^{*}$ & 5,906 & 0,007 \\
\hline & $\mathrm{KN}$ & $-48.200^{*}$ & 5,906 & 0,000 \\
\hline & $\mathrm{KP}$ & $-7,600$ & 5,906 & 1,000 \\
\hline & $\mathrm{P} 2$ & $-11,400$ & 5,906 & 0,679 \\
\hline \multirow[t]{4}{*}{$\mathrm{P} 2$} & KM & $-12,400$ & 5,906 & 0,487 \\
\hline & $\mathrm{KN}$ & $-36.800^{*}$ & 5,906 & 0,000 \\
\hline & $\mathrm{KP}$ & 3,800 & 5,906 & 1,000 \\
\hline & $\mathrm{P} 1$ & 11,400 & 5,906 & 0,679 \\
\hline
\end{tabular}

Analisis statistik post hoc bonferroni kadar glukosa darah pada tabel 4 menunjukkan adanya perbedaan yang bermakna pada semua kelompok KN yaitu
$\mathrm{KN}$ dengan $\mathrm{KM}$ dengan nilai $\mathrm{p}=0,005, \mathrm{KN}$ dengan $\mathrm{KP}$ dengan nilai $\mathrm{p}=0,000, \mathrm{KN}$ dengan $\mathrm{P} 1$ dengan nilai $\mathrm{p}=0,000$, dan $\mathrm{KN}$ dengan $\mathrm{P} 2$ dengan nilai $\mathrm{p}=0,000$.

\section{PEMBAHASAN}

Perbandingan antara kelompok kontrol murni (KM) dengan kelompok kontrol positif (KP) dengan nilai uji sebesar $\mathrm{p}=$ 0,125 yang berarti tidak adanya perbedaan yang signifikan antara kedua kelompok tersebut. Kelompok positif (KP) merupakan kelompok dengan pemberian metformin dengan dosis $45 \mathrm{mg} / \mathrm{kgBB}$ dan diinduksi aloksan dengan dosis $125 \mathrm{ml} / \mathrm{kgBB}$. Penelitian ini sejalan dengan penelitian yang dilakukan oleh Grace Laury Tulung, (2020) menggunakan metformin yang diberikan pada hewan coba tikus, hasilnya menunjukan pemberian metformin dapat menurunkan kadar glukosa darah tikus yang diinduksi aloksan (Grace Laury Tulung, 2020). Metformin dapat mencegah hiperglikemia tetapi tidak menyebabkan hipoglikemia. Metformin mempunyai efek utama mengurangi glukosa hati (gluconeogenesis), dan memperbaiki ambilan glukosa di jaringan perifer (Ritter .J, 2019).

Pada kelompok kontrol murni (KM) dengan kelompok perlakuan 1 (P1) terdapat perbedaan yang signifikan dengan nilai $\mathrm{p}=$ 0,007. Dapat dilihat pada perbandingan rerata kadar glukosa akhir pada kelompok ini $(124,6 \pm$ SD 8,47) dan adalah $(100,8 \pm$ SD 5,40).Pada kelompok perlakuan 1 (P1) ini merupakan kelompok dengan perlakuan pemberian ekstrak habbatussada (Nigella sativa) dengan dosis $150 \mathrm{mg} / \mathrm{kgBB}$ dan diinduksi aloksan dengan dois $125 \mathrm{ml} / \mathrm{kgBB}$ mengalami penurunan kadar glukosa yang paling rendah. Penelitian ini sejalan dengan penelitian yang dilakukan oleh Kriswandini, (2012) menggunakan ekstrak habbatussauda sebanyak $150 \mathrm{mg} / \mathrm{kgBB} / \mathrm{hari}$ yang diberikan secara intraperitoneal kepada hewan coba tikus putih jantan, hasilnya menunjukkan bahwa penggunaan ekstrak habbatussauda kepada hewan coba tikus putih dengan dosis sebanyak $150 \mathrm{mg} / \mathrm{kgBB} /$ hari efektif dapat 
menurunkan kadar glukosa darah dan juga dapat memperbaiki tingkat kerusakan pulau Langerhans (Kriswandini, 2012)

Menurut Pudjono (2006), menyatakan bahwa etanol nerupakan pelarut protik yang sanggup sebagai donor proton sehingga mengadakan ikatan hidrogen dengan enolat yang terbentuk dari habbatussauda, semakin polar pelarut maka akan semakin kuat ikatan hidrogen yang terbentuk. Akibatnya tidak terhomogennya secara merata antara pelarut dan habbatussauda sehingga pelarut tersebut menyebabkan kerusakan pada jaringan pulau langerhans, walaupun terjadi perbaikan tetapi tidak akan maksimal (Pudjono, 2006).

Pada perbandingan kelompok kontrol negatif (KN) didapatkan perbedaan yang signifikan dengan semua kelompok percobaan. Tetapi kelompok yang mengalami perbedaan yang signifikan adalah dengan kelompok kontrol positif (KP), kelompok perlakuan 1 (P1), dan kelompok perlakuan 2 (P2) dengan nilai $p$ $=0,000$ pada ketiganya. Aloksan merupakan salah satu senyawa kimia yang dimanfaatkan untuk menginduksi hewan penelitian untuk menghasilkan keadaan diabetes eksperimental (hiperglikemik) secara cepat. Pemberian senyawa aloksan dapat dilakukan dengan cara intraperitoneal, intravena maupun subkutan. Kemampuan aloksan yang menimbulkan efek diabetes juga bergantung pada dosis yang diberikan, jalur pemberian induksi, hewan percobaan dan status gizi pada hewan tersebut (Rochmawati ayu, 2018). Hal ini menjadi dugaan adanya perbedaan yang signifikan pada kelompok kontrol negatif $(\mathrm{KN})$ dengan seluruh kelompok percobaan, dengan rerata kadar glukosa paling tinggi diantara yang lainnya yaitu sebesar (149 \pm SD 14,90).

Kemudian pada kelompok uji coba kontrol positif (KP) didapatkan perbedaan hanya dengan kelompok kontrol negatif $(\mathrm{KN})$ saja dengan nilai $\mathrm{p}=0,000$. Tidak ada perbedaan signifikan antara kelompok kontrol positif (KP) dengan kelompok kontrol murni (KM), kelompok perlakuan 1 (P1), dan kelompok perlakuan 2 (P2).
Pemberian metformin dapat mengurangi produksi glukosa di hati (glukoneogenesis) dan penurunan resistensi insulin pada pasien penderita Diabetes Mellitus. Efek pemberian metformin sama dengan efek pemberian ekstrak habbatussada (Nigella sativa) yang dapat menurunkan kadar glukosa darah pada tubuh. Sehingga pada kelompok kontrol positif (KP) dengan kelompok perlakuan 1 (P1) dan kelompok perlakuan 2 (P2) tidak terdapat perbedaan yang signifikan.

Untuk kelompok perlakuan 1 (P1) terdapat perbedaan yang signifikan dengan kelompok murni $(\mathrm{KM})$ dengan nilai $\mathrm{p}=$ 0,007 dan kontrol negatif (KN) dengan nilai $\mathrm{p}=0,000$. Terlihat nilai uji Post Hoc lebih signifikan dengan kelompok kontrol negatif (KN) yang diinduksi aloksan. Dalam penelitian ini, hewan uji coba diiinduksian dengan senyawa aloksan untuk mendapatkan kondisi diabetik eksperimental dalam waktu yang singkat. Senyawa aloksan merupakan derivat siklikurea yang memiliki efektivitas tinggi terhadap agen diabetogenik untuk menginduksi keadaan diabetik eksperimental. Senyawa aloksan dapat menyebabkan kerusakan sel $\beta$ pankreas dengan cara membentuk struktur ROS sehingga mengganggu induksi ataupun sekresi dari insulin (Radenkovic et. al., 2016).

Kelompok perlakuan 2 (P2) yang diberikan ekstrak habbatussada (Nigella sativa) dengan dosis $300 \mathrm{mg} / \mathrm{kgBB}$ dan diinduksi aloksan dengan dosis 125 $\mathrm{ml} / \mathrm{kgBB}$ memiliki perbedaan yang signifikan hanya dengan kelompok kontrol negatif $(\mathrm{KN})$ dengan nilai $\mathrm{p}=0,000$. Tidak ada perbedaan signifikan antara kelompok perlakuan 2 (P2) dengan kelompok kontrol murni (KM), kelompok kontron positif (KP), dan kelompok perlakuan 1 (P1).

Pada penelitian ini dilakukan pemberian ekstrak habbatussauda (Nigella sativa) untuk upaya preventif penurunan kadar glukosa darah. Hasil analisis uji paired t-test menunjukkan kadar glukosa darah pada kelompok P1 dan P2 terdapat 
perbedaan yang signifikan $(\mathrm{p}<0,05)$. Pada analisis post hoc perbedaan terdapat pada kelompok $\mathrm{P} 1$ dengan $\mathrm{KN}$ dengan nilai $\mathrm{p}=$ 0,000 dan $\mathrm{P} 2$ dengan $\mathrm{KN}$ dengan nilai $\mathrm{p}=$ 0,000. Berarti pada pemberian ekstrak habbatussauda terdapat pengaruh dalam penurunan kadar glukosa darah tikus. Penelitian ini sejalan dengan penelitian yang dilakukan Haddad A. El Rabey, (2017) mengguakan ekstrak habbatussauda (Nigella sativa) yang diberrikan secara oral pada tikus, hasilnya secara signifikan mengurangi hiperglikemia dan stres oksidatif pada tikus dengan kondisi hiperglikemia (Haddad A. El Rabey, 2017). Hal ini menunjukan bahwa pemberian ekstrak habbatussauda mempunyai efek hipoglikemik atau mampu menurunkan kadar glukosa darah. Efek ini merupakan hasil kerja dari zat yang terkandung dalam ekstrak habbatusauda yaitu thymoquinone.

\section{KESIMPULAN}

Terdapat pengaruh pemberian ekstrak habbatussauda (Nigella sativa) terhadap kadar glukosa darah tikus putih (Rattus norvegicus) galur wistar jantan yang diinduksi aloksan sebagai upaya preventif hiperglikemia. Diketahui rerata akhir kadar glukosa darah tikus putih (Rattus norvegicus) galur Wistar jantan yang tidak diberi perlakuan yaitu sebesar $(124,6 \pm$ SD $8,47)$.Diketahui rerata akhir kadar glukosa darah tikus putih (Rattus norvegicus) galur Wistar jantan yang diinduksi aloksan dengan dosis $125 \mathrm{ml} / \mathrm{kgBB}$ yaitu sebesar (149 \pm SD 14,90). Diketahui rerata akhir kadar glukosa darah tikus putih (Rattus norvegicus) galur Wistar jantan yang diberi metformin dengan dosis $45 \mathrm{mg}$ dan diinduksi aloksan dengan dosis 125 $\mathrm{ml} / \mathrm{kgBB}$ yaitu sebesar $(108,4 \pm \mathrm{SD} 9,52)$. Diketahui rerata akhir kadar glukosa darah tikus putih (Rattus norvegicus) galur Wistar jantan yang diberi ekstrak habbatussauda (Nigella sativa) dengan dosis $150 \mathrm{mg} / \mathrm{kgBB}$ dan diinduksi aloksan dengan dosis 125 $\mathrm{ml} / \mathrm{kgBB}$ yaitu sebesar $(100,8 \pm \mathrm{SD} 5,40)$. Diketahui rerata akhir kadar glukosa darah tikus putih (Rattus norvegicus) galur Wistar jantan yang diberi ekstrak habbatussauda (Nigella sativa) dengan dosis $300 \mathrm{mg} / \mathrm{kgBB}$ dan diinduksi aloksan dengan dosis 125 $\mathrm{ml} / \mathrm{kgBB}$ yaitu sebesar (112,2 $\pm \mathrm{SD} 4,71)$. Dan Diketahui dosis optimal pemberian ekstrak habbatussauda (Nigella sativa) sebagai upaya preventif hiperglikemia yaitu pada dosis $150 \mathrm{mg} / \mathrm{kgBB}$

\section{UCAPAN TERIMAKASIH}

Ucapan terimakasih diucapkan kepada semua pihak yang telah terlibat dalam penelitian ini sehingga pengetahuan yang terdapat dalam penelitian ini dapat dituangkan dalam bentuk tulisan dan diinformasikan kepada pembaca.

\section{DAFTAR PUSTAKA}

Benhaddou-Andaloussi,A., Martineau, L. C., Spoor, D., Vuong, T., Leduc, C., Joly, E., \& Prentki, M. (2008). Antidiabetic activity of Nigella sativa. Seed extract in cultured pancreatic $\beta$ cells, skeletal muscle cells, and adipocytes. Pharmaceutical Biology, 46(1-2), 96-104.

Grace Laury Tulung, W. B. (2020). UJji Efektivitas Ekstrak Etanol Daun Pegagan (Centella asiatica (L.) Urban) Sebagai Antidiabetes Terhadap Tikus Putih Jantan (Rattus norvegicus) Yang Diinduksi Aloksan. PharmaconProgram Studi Farmasi, FMIPA, Universitas Sam Ratulangi.

Haddad A. ElRabey, M. N.-S. (2017). The Antidiabetic Activity of Nigella sativa and Propolis on StreptozotocinInduced Diabetes and Diabetic Nephropathy in Male Rats. Hindawi Publishing Corporation EvidenceBased Complementary and Alternative Medicine .

Husna, M. (2008). Pengaruh Pemberian Minyak Jinten Hitam (Nigella sativa L.) Terhadap Kadar Glukosa Darah Pada Tikus Diabetes Akibat Induksi Aloksan. 
International Diabetes Federation (IDF). (2015).Diabetes Atlas.seventh Ed. UK: International Diabetes Federation Kaleem, M., Kirmani, D., Asif, M., Ahmed, Q., Bano, B., (2006). Biochemical effects of Nigella sativa $L$ seeds in diabetic rats. Indian J. Exp. Biol. 44, 745-748

Kanter, M., I. Meral, Z. Yener, H. Ozbek, H. Demir, (2003). Partial regeneration / proliferation of the beta-cells in the islets of Langerhans by Nigella sativa L. in streptozotocin-induced diabetic rats. Tohoku J Exp Med. 201 (4) : 213 9. Kesehatan, K., 2013. Riset Kesehatan Dasar (Riskesdas). Kemenkes RI.

Kriswandini, L. (2012). Efek antihiperglikemik ekstrak biji jintan hitam (nigella sativa) pada tikus model diabetes tipe II (Doctoral dissertation, Universitas Islam Negeri Maulana Malik Ibrahim).

PERKENI. (2019). Pedoman Pengelolaan dan Pencegahan Diabetes Mellitus Tipe 2 di Indonesia. Jakarta : PB PERKENI

Radenkovic, et al., (2016). Experimental diabetes induced by alloxan and streptozotocin: The current state of the art. Journal of Pharmacological and Toxicological Methods

Ritter, J., Flower, R.J., Henderson, G., Loke, Y.K., MacEwan, D.J. and Rang, H.P., (2019). Rang and Dale's Pharmacology.

Rochmawati, Ayu, and Syahrul Ardiansyah. (2018.) Uji Aktivitas Antidiabetes Ekstrak Bonggol Nanas (Ananas Comusus L.) Pada Tikus Yang Di Induksi Aloksan. Medicra (Journal of Medical Laboratory Science/Technology). 